\title{
LUNG ECHINOCOCCAL CYST IN A CHILD
}

\author{
Danijela Ilic ${ }^{1}$, Andjelka Stojkovic ${ }^{2}$, Slobodan Obradovic ${ }^{2}$ \\ ${ }^{1}$ Health Centre, Rekovac, Serbia \\ ${ }^{2}$ Paediatric Clinic, Clinical Centre "Kragujevac", Kragujevac, Serbia
}

\section{EHINOKOKNA CISTA PLUĆA KOD DETETA}

\author{
Danijela Ilićl, Andjelka Stojkovićc, Slobodan Obradović ${ }^{2}$ \\ ${ }^{\prime}$ Dom zdravlja, Rekovac \\ 2Pedijatrijska klinika, Klinički centar "Kragujevac”, Kragujevac, Srbija
}

\begin{abstract}
Lung echinococcal cyst is a rare clinical manifestation in children in non-endemic areas. The aim of this paper is to present unusual clinical manifestations of the lung echinococcus in a child and to discuss the current knowledge about the disease, options for a fast and accurate diagnosis, as well as the need for surgical treatment.

The case study presents a child aged 6 years and 7 months, admitted to the Pediatric Clinic for pneumonia and pneumothorax. The onset of the disease was sudden, a day prior to the hospital admission, with abdominal pain, fever, irritated cough, without expectoration. The chest X-rays, hematological and serological analysis confirmed the diagnosis of a large infected echinococcal cyst of the right lung in the lower and middle lobe. During hospitalization clinical improvement was achieved, with normalization of the respiratory function but fever continued. On the fifth day of the hospitalization, the child was referred to a surgery, which included the lobectomy of the right lung. Having in mind that the echinococcal cyst grows about $3 \mathrm{~cm}$ per year, it was postulated that the infection with echinococcus happened in the second year of the patient's life and that it remained asymptomatic for a long time.

Epidemiological data are important for diagnosing the lung echinococcal disease. Administration of antimicrobials during perioperative management of the echinococcal cyst is useful treatment option when significant perifocal inflammatory reaction exists.
\end{abstract}

Key words: echinococcus; cysts; lung; child, preschool; case report.

\section{INTRODUCTION}

Lung echinococcal cyst is mostly a primary illness in children. About two thirds of echinococcus grows in the lungs. In $10 \%$ of the infected children, the echinococcal cyst of the liver is also present (1). Echinococcus of the lungs in children can be followed by the pain in the thorax. Research findings of the last decade show that echinococcus of the lungs in children is often without any symptoms, or if there are any, it is followed by unusual manifestations due to a long-term and unrecognized disease (2). Echinococcus in the lungs grows about $3 \mathrm{~cm}$ per year (3). If manifested, complications include the

\section{SA ŽETAK}

Ehinokokna cista pluća je retka klinička manifestacija kod dece izvan endemskih područja. Cilj ovog rada je da prikaže neobične kliničke manifestacije ehinokokusa pluća kod deteta i da diskutuje sadašnja znanja o oboljenju, opcije za brzu i preciznu dijagnozu, kao i potrebu za hirurškim lečenjem.

U radu se analizira slučaj deteta uzrasta 6 godina $i 7$ meseci hospitalizovanog zbog pneumonije i pneumotoraksa. Tegobe su počele naglo, dan pre prijema u bolnicu, bolom $u$ trbuhu, povišenom temperaturom, nadražajnim kašljem bez iskašljavanja. Rentgengrafijom pluća, hematološkim $i$ serološkim analizama dijagnostikovana je velika inficirana ehinokokna cista desnog pluća u donjem i srednjem plućnom polju. Tokom hospitalizacije postignuto je kliničko poboljšanje sa normalizacijom respiratorne funkcije, ali se febrilnost održavala. Petog dana hospitalizacije dete je upućeno na operativno lečenje ehinokokne ciste pluća koje je uključilo lobektomiju desnog pluća. S obzirom da ehinokokna cista raste oko $3 \mathrm{~cm}$ godišnje pretpostavljeno je da se infekcija ehinokokusom dogodila u drugoj godini života $i$ da je dugo ostala asimptomatska.

Epidemiološki podaci su značajni za dijagnozu ehinokokne bolesti pluća. Primena antimikrobnih lekova tokom perioperativnog tretmana ehinokokne ciste je korisna terapijska opcija kada postoji značajna perifokalna inflamatorna reakcija.

Ključne reči: ehinokokus; cista; pluće; dete, predškolsko; prikaz slučaja.

following symptoms: cough, breathing difficulties and bleeding from the lungs. If the echinococcal cyst ruptures, its contents leaks into a bronchial tree, which can lead to immediate choking or the symptoms of anaphylaxis appear.

Exudative pleuritis is rarely manifested, as a consequence of a strong reaction of pleura, as well as of an infection spreading to a pleural cavity. The most severe complication is the infection of the echinococcus which develops after the rupture of the pericyst and the development of the bronchial fistulae. This complication manifests itself with the symptoms of a lung abscess or 
with the symptoms of pleural empyema. The erosion of a larger blood vessel and communication with the bronchus are followed by hemoptysis, rarely by embolism and spread of echinococcus into other organs (1-5).

The most important diagnostic procedures are radiological examinations, computerized tomography (CT) of the thorax and abdomen, as well as serological analysis for Echinococcus. According to a peripheral smear, a mild to moderate eosinophilia is found in $25-70 \%$ of the infected children $(4,5)$. The operation is a primary treatment option, when the therapy of the echinococcal cyst is in question. The procedure which often follows is a lung lobectomy.

\section{THE CASE}

A girl, aged 6 years and 7 months, was admitted to the Pediatric Clinic for suspected pneumonia and pneumothorax. The onset of the disease was sudden, a day prior to the hospital admission, with vomiting and irritated cough, without expectoration. After she had been examined by a pediatrician at the Clinic, salbutamol and cefixime were administered. During the night, she developed a high fever $\left(38.7^{\circ} \mathrm{C}\right)$ and she complained of abdominal pain and choking and she has been hospitalized at the General Hospital in Gornji Milanovac. On that same day she was referred to the Pediatric Clinic of the Clinical Centre of Kragujevac.

Anamnesis showed us that the girl had been healthy up to that moment, that she lived in a rural area where keeping dogs and cats was common, and that she had came in contact with them. At the admission the girl was conscious, febrile $\left(38^{\circ} \mathrm{C}\right)$, dyspneic, hypotrophic, with body mass (BM) of $20 \mathrm{~kg}$ and body height $(\mathrm{BH}) 120 \mathrm{~cm}$. Her body mass index (BMI) was $13.88 \mathrm{~kg} / \mathrm{m} 2$. A weakened breathing sound on the right side, basally, was found as well as in the mid parts of the right hemithorax. She had 48 respirations per minute and oxygen saturation

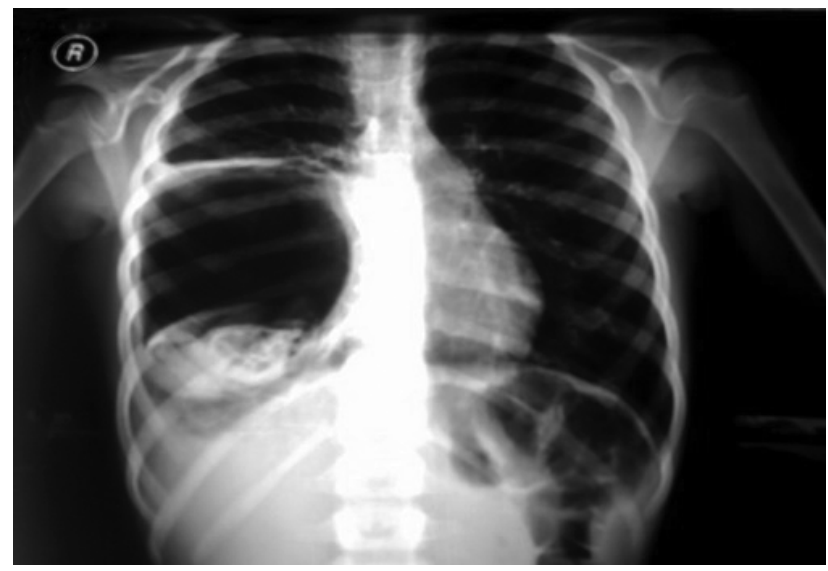

Figure 1. Frontal view of the chest shows that a lung echinococcal cyst occupies the lower and the mild lobe of the right lung. of $94 \%$ (measured with a percutaneous oxymetre at room temperature - $\mathrm{SaO} 2$ ). All other physical findings were normal.

The laboratory analysis showed a rise in the inflammatory parameters: erythrocyte sedimentation rate (ESR) $32 \mathrm{~mm}$, C-reactive protein (CRP) $73.6 \mathrm{mg} / \mathrm{L}$, procalcitonin (PCT) $4.15 \mathrm{ng} / \mathrm{mL}$ and fibrinogen $6.83 \mathrm{~g} / \mathrm{L}$. Hematological smear showed leukocytosis, with a predominance of neutrophils (87\%) and eosinophils (4\%) with absolute count of 688 per $\mathrm{mm}^{3}$. Also, a four times higher value of alpha-1-antitrypsin (A1AT) was recorded $(2.1 \mathrm{~g} / \mathrm{L})$, as well as a four times higher antibody titers IgG for echinococcus than normal (41.9 U/L). Other biochemical analyses, such as the red blood cells count (RBC), platelets count (PLT), hemoglobin (Hg), hematocrit (Hct), plasma electrolytes, aspartate aminotransferase (AST), alanine aminotransferase (ALT), alkaline phosphatase (ALP), gamma-glutamyl transpeptidase (GGT), lactate dehydrogenase (LDH) and urine, were within the reference value range.

The chest X-ray (figure 1) showed a large circular mass, clearly bordered $(13 \times 19 \mathrm{~cm})$ in the mid and lower lung area of a right hemithorax, with a bizarre hyperdense content - shadow and a large airy-transparent part with a formed level. A profile chest X-ray (figure 2), showed that the mass is located in the medial and posterior segments, pressing the remaining part of the parenchyma and mediastinal structure to the left. An ultrasonography of the abdomen showed the hyperechogenic liver.

During the initial hospital stay, fever rise up to $40^{\circ} \mathrm{C}$, with a septic pattern. The girl was occasionally dyspneic and tachypneic, with a fall in oxygen saturation up to $91 \%$ at room temperature. A working diagnosis was established - a large echinococcus lung cyst in the right hemithorax, with an infection of the surrounding lung parenchyma. The diagnosis was later verified serologically.

The treatment included oxygen, bronchodilatators (salbutamol) and antimicrobials (ceftriaxone, amikacin,

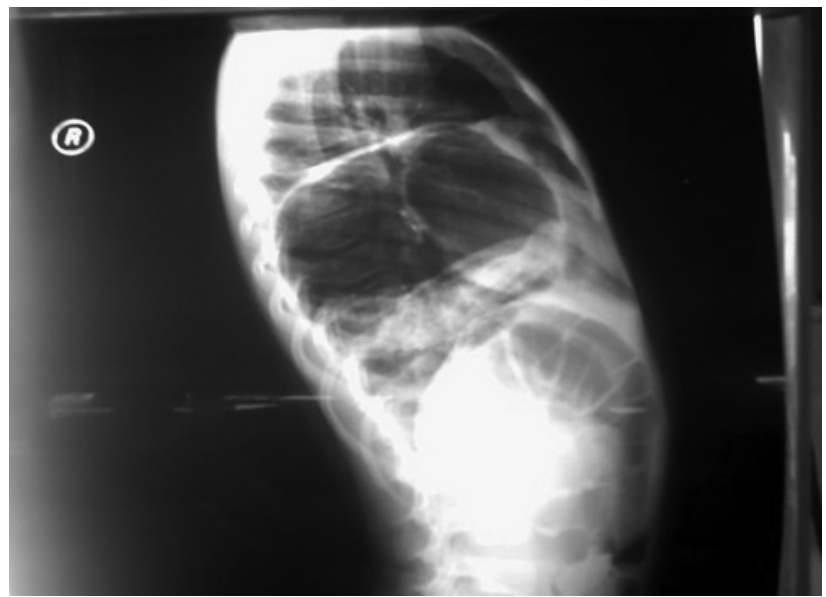

Figure 2. Right lateral view of the chest shows a medioposterior visualisation of the echinococcal cyst. 
and metronidazole). On the fourth day of hospitalization, clinical improvement was observed: oxygen saturation was normalized at $97 \%$ and the number of respirations was 28 per minute. The inflammatory parameters were declining in 24 hours and CRP fell from 73.6 to 65.3 $\mathrm{mg} / \mathrm{L}$. On the fifth day of hospitalization the girl was sent to the surgery ward for definitive echinococcal cyst removal.

\section{DISCUSSION}

There are two types of echinococcus that can infect a person in Europe. The most common is Echinococcus granulosus. A child gets infected with echinococcus, namely eggs of Taenia echinococcus, which are transmitted through fasces of a dog, cat or fox, and are inserted into one's organism through dirty hands and ingestion. An embryo, via portal bloodstream, enters directly into the liver and subsequently into the lungs. Five to six months later, an echinococcal cyst, consisting of cuticle, epithelium and clear fluid, is developed. The organism creates a binding cocoon or a pericyst around it.

Clinical features of the girl could point to following possible diagnosis: lung echinococcus, lung abscess, infected bronchial lung cyst (congenital or acquired), lung or mediastinal tumors, primary ciliary dyskinesia, cystic fibrosis and, less frequently, arteriovenous fistula, benign granuloma, aspergillosis of the lungs, Loeffler's syndrome and Birt-Hogg-Dube syndrome $(6,7)$. The child complained of health problems immediately prior to the hospital admission, which was seen in a small number of children infected with echinococcus. It is common for a clinical feature of a large lung echinococcal cyst to gradually develop.

Radiological findings for echinococcus disease are pathognomonic, showing a clearly bordered circular shadow. Since the cyst was infected, it had smaller hyperdense content - a shadow, and a larger airytransparent part, with a formed level. A characteristic sign on the surface of the fluid, in the shape of a water lily, was not present, indicating that the cyst had not perforated, which was the reason for the absence of expectoration.

Blood peripheral smear in the girl showed a mild eosinophilia $(4 \%, 688$ per $\mathrm{mm} 3)$ which was somewhat higher than the upper normal limits $(<3 \%, 218$ per mm3) suggesting a helmintic infestation $(5,7)$. A1AT was four times higher, which indicated the florid inflammatory process suggesting possible necrosis of the echinococcal cyst and surrounding tissue (4). A1AT can be raised in echinococcal cyst, some inflammatory disease, some malignant tumours and after corticosteroids and oestrogen treatment abscess is caused by many bacteria (Staphylococcus aureus, Streptococcus pneumoniae, Haemophilus influenzae, Moraxella catarrhalis, Klebsiella pneumoniae, Escherichia coli, Bacteroides, Peptococcus and Fusobacterium) and it is also considered in differential diagnosis. The clinical features of lung abscess of the lungs are similar with the course of the diseases in our patient: a sudden onset, high fever with the septic pattern and the increase of inflammatory parameters (8). Fungal infections are also considered primarily aspergillosis. Lungs aspergillosis would manifest itself in the form of a multiple smaller abscesses, lobar pneumonia or hemorrhagic lung arrest, especially with children with a cellular immunity disorder (2) but detailed work up excluded the cytokines of inflammation, as interleukins IL3 and IL5, and immunoglobulins IgE and IgM rise together with eosinophilia accounts. In lungs aspergillosis eosinophilia is mild (over 1000 per $\mathrm{mm}^{3}$ ) (2).

Other causes of eosinophilia were also excluded as possible causes. Loeffler's syndrome, appearing as a consequence of the transfer of diverse parasites (Ascaris, Taenia, Ancylostoma, Trichuris, Fasciola, Toxicara) through the lungs during their life cycle have higher eosinophilia than values in our case $(10-40 \%, 1000-5000$ cells per mm3) $(2,5)$. Idiopathic hypereosinophilic syndrome is characterized by the absence of parasitosis and allergic illness, with eosinophilia ( $>1500$ cells per $\mathrm{mm}^{3}$, for six months or longer), or a leukocytosis higher than 30.000 cells per $\mathrm{mm} 3$ with hypereosinophilia of 50 $90 \%(2,9)$.

The child's age made less likely the presence of congenital bronchial lung cyst because it would have manifested itself earlier but an acquired bronchial cyst (acutely infected) was in consideration. Pulmonary arteriovenous fistulae were also less possible since they are always localized in the hilum and manifested with hemoptysis. Finally, tumors of the lungs and mediastinum were also carefully excluded after consideration of all clinical features.

The first phase of treatment course was based on the supportive measures and antibiotic administration, with the purpose of treating the inflammation surrounding the echinococcal cyst, caused by mixed, gram-positive, gramnegative bacteria as well as anaerobic flora. Some authors suggest that mebendazole, $(50-60 \mathrm{mg} / \mathrm{kg})$ should be administered in three doses within the three months after the surgery as a specific antihelmintic agent $(2,4,5,10)$. The definitive treatment in our patients was surgery for cyst removal. Complications in children with echinococcus of the lung after the surgery are practically negligible, which is why the prognosis is good. Our patients also recovered The inflammatory parameters declined on the second day of hospitalization despite of persist fever, adynamia and pale-grey skin.

In conclusion, lung echinococcal cyst is a rare clinical manifestation in children in non-endemic areas and pediatricians could be vigilant for symptoms and signs of 
this disease. Detailed clinical examination, appropriate imaging diagnostic and laboratory tests allowed physician to established proper and timely diagnosis. The first treatment choice is the surgery but medications, including antimicrobial and antihelmintic agents, could significantly help in complete recovery, particularly in complicated cases or unusual presentation.

\section{REFERENCES}

1. Zergolen Lj. Pediatrics. Zagreb: Naprijed, 1994 (in Serbo-Croatian)

2. Milovic I, Rosic R. Echinococcal lung cysts - unusual manifestations. Problems in Pediatrics 1995: 124-30 (in Serbian)

3. Nestorovic B. Echinococcosis. Pediatric Pulmology 2001; 284: 361-2. (in Serbian)

4. Chernik V, Boat T. Kendig's disorders of the respiratory tract in children. Philadelphia: WB Saundres Co, 1998.
5. Morar R, Feldman C. Pulmonary echinococcosis. Eur Respir J 2003; 21: 1069-77.

6. Barbato A, Frischer T, Kuehni EC, Snijders D, et al. Primary ciliary dyskinesia: a consensus statement on diagnostic and treatment approaches in children. Eur Respir J 2009; 34: 1264-76.

7. Frohlich AB, Zeitz C, Matyas G, Alkadhi H, Tuor C, Berger W, Russi WE. Novel mutations in the folliculin gene associated with spontaneous pneumothorax. Eur Respir J 2008; 32: 1316-20.

8. Barbato A, Bertuola F, Kuehni C, et al. Pediatrics in Berlin. Eur Respir J 2009; 34: 436-43.

9. Ajitsaria R, Awad IW, Jaffe A, et al. Congenital lung abnormality in a 1-yr old. Eur Respir J 2004; 23: 348-51.

10. Kliegman R, Behrman R, Jenson BH, Stanton FB. Nelson textbook of Pediatrics. 18th Edition. Philadelphia: WB Saunders Company, 2008; 301-5. 